\section{Reenacting Reality: An Exploration of Richard Nixon in Frost/Nixon}

\author{
Alexandra Rocca
}

Senior, History

A black screen. There is the beat of a steady drum, akin to the strum of a drumline at the gallows. As the screen is bathed in light, two subjects sit opposite of each other: on one side, British talk show host David Frost; the other, former disgraced President Richard Nixon. The year is 1977, it is Richard Nixon's comeback for redemption after his resignation from the presidency three years earlier. The events that unfold become known as the Frost/Nixon interviews and are later immortalized in the 2008 film, Frost/Nixon. As a man, Nixon is infamously remembered as Tricky Dick, with a character that is chiefly viewed as mysterious and perplexing. No film has explored this seemingly impenetrable individual as effectively as Frost/Nixon. With its largely faithful reenactments and its attempt to understand Richard Nixon rather than judge, Frost/Nixon is a film that honors both cinematic entertainment and historical fact.

Although Frost/Nixon offers an indepth, graphic account of the Frost/Nixon interviews on and off the screen, and scrutinizes the complex persona of President Richard Nixon, the film reveals little about its pivotal subject's background. One who watches the film with no prior knowledge of Nixon nor the Watergate scandal may be left ignorant to its significance. Since Frost/Nixon assumes that the audience is already aware of his career and infamy, it is crucial to contextualize Nixon before extensively exploring the film. The 37 th President of the
United States was born on January 9, 1913, and grew up amid humble surroundings in Yorba Linda, California. ${ }^{1}$ As a boy, Nixon lived a modest Quaker life and endured the loss of two brothers to tuberculosis. ${ }^{2}$ Early hardships and disadvantages inspired the young Nixon to work industriously, and he eventually paved his way to law school at Duke University in North Carolina. ${ }^{3}$ After private practice and government service, he volunteered for the navy in April 1942, during the Second World War. Nixon's status as a veteran helped launch his political career. ${ }^{4} \mathrm{He}$ won a seat in the House of Representatives for California's Twelfth Congressional District at the age of 33, then went on to win a seat in the Senate in 1950 . He progressed to serving as Vice President under President Dwight D. Eisenhower from 1953 to $1961 .^{5}$ As Vice President, Nixon's steely wit complemented Eisenhower's affability. In 1959, he was acclaimed for his performance in the infamous Moscow "kitchen debate" with Soviet Premier Nikita Khrushchev. ${ }^{6}$

During Nixon's tenure as Vice

President, he attempted his own ascent to the presidency in the election of 1960, but lost against Democrat John F. Kennedy. His defeat was foreshadowed in the first televised debate in U.S. history: Kennedy shone with his youth and dashing confidence, while Nixon sweated stoically. In 1962, Nixon ran for Governor of California and lost again. ${ }^{7}$ Failure did not deter Nixon though, it only stoked his determination. After spending some years setting up a successful law practice in New York, he ran for president again in 1968. He won, attributing his victory to his championing of America's "silent majority" who yearned for the restoration of "law and order" in the tumultuous $1960 \mathrm{~s}^{8}{ }^{8}$

As President, Nixon primarily focused on foreign affairs. He had to face the Vietnam 
War, which cast a dark shadow over predecessor Lyndon Johnson's administration, and would become the first lost war in U.S. history. With Henry Kissinger as his aide, and later Secretary of State, Nixon slowly withdrew American troops while backing the South Vietnamese. ${ }^{9}$ He eased Cold War tensions with visits to the communist capitals of China and the Soviet Union in $1972 .{ }^{10}$ At home, Nixon notably attempted welfare reform but the plan was killed by an oftenresistant Congress. ${ }^{11}$ His foreign policy success won him the presidency again in 1972, one of the biggest landslides in US history. ${ }^{12}$ Despite Republicans' general ardor for Nixon, he had fostered an adverse relationship with democrats, which ultimately prompted his involvement in Watergate.

After five men broke into the Democratic National Committee headquarters at the Watergate Hotel in Washington, DC, it was discovered that some had ties to the White House. ${ }^{13}$ It was brought to light that Nixon and his aides had been involved in numerous illegal acts, including bugging opponents' offices and searching through private records; they attempted a cover-up by paying off operatives and censoring transcripts of secretly taped conversations recorded in the Oval Office. ${ }^{14}$ The scandal rocked the country to its core. Upon impeachment proceedings, Nixon resigned on August 9, 1974, with no admission of wrongdoing. ${ }^{15}$ He later admitted to his failures in a 1977 televised interview series with British talk show host David Frost, the event of which Frost/Nixon chronicles.

Though Frost/Nixon mainly takes place during the interviews in 1977, the film opens after the Watergate scandal in 1974, showing how Nixon shocked the world by becoming the first president in United States history to resign amid threats of impeachment.
Frost, a British talk show host known for his frivolity and womanizing, is among the 400 million watching the President's resignation. He is immediately inspired and decides he wants to interview Nixon, knowing the success that would ensue. Frost contacts Nixon's literary agent, Irving “Swifty” Lazar, with an offer of $\$ 500,000$ out of pocket. Lazar, knowing Frost to be a "lightweight" interviewer, sees the opportunity for Nixon to salvage his reputation, and agrees for a fee of $\$ 600,000$. Frost gets to work, and hires a team of "crack" investigators, James Reston, Jr. and Bob Zelnick, who are determined to "Give Richard Nixon the trial he never had."16 The Frost and Nixon teams agree to 28 hours of taping, which would be cut into four 90minute specials: Foreign policy, domestic policy, Nixon's personal life, and Watergate. Frost seems unconcerned in the period leading up to the interviews, while Reston and Zelnick warn him to be wary of "Tricky Dick". Under the scrutinizing eye of Nixon's chief-of-staff, Jack Brennan, Frost and Nixon commence the interviews. In the seconds before the cameras begin rolling before one session, Nixon inquires, "Did you do any fornicating [last night]?"-Frost is nearly rendered speechless for an initial moment on camera. ${ }^{17}$ "Tricky Dick", indeed. Nixon dominates the first three interviews. Frost attempts to constrain him with difficult questions, but Nixon rambles his way around them. Frost's team is furious that Nixon is effectively exonerating himself, and Frost realizes that the interviews will be a debacle if the Watergate interview continues in the same fashion. Days before the final interview, Frost receives a late-night phone call from Nixon. Inebriated, Nixon rants about how the two of them emerged from humble backgrounds and had to fight their way to the top. He acknowledges that the interviews will make one's career and break the other's, and 
vows to do everything in his power to emerge as the final victor. Frost springs into action, feverishly preparing for the impending Watergate interview. As the final taping begins, Frost presents Nixon with recently uncovered, damning evidence that Nixon was involved in the Watergate cover up. Nixon rebuts in a culminating moment, "When the president does it, that means it is not illegal."18 Brennen immediately emerges and halts the session, urging Nixon to reconsider proceeding with the interview. Nixon declines, and as the cameras roll again, he admits to participating in the Watergate cover up and apologizes for letting the American people down. The interviews conclude and are a success when they air. Frost and Nixon cordially meet one more time with Nixon admitting defeat. As Frost turns to leave, he mentions Nixon's surprise phone call. A perplexed Nixon responds, "What phone call?"19 The film ends; an epilogue states that Nixon never escaped controversy until his death in 1994.

Directed by Ron Howard, Frost/Nixon was released in late 2008 for limited release and early 2009 for wide release. ${ }^{20}$ It is based on the 2006 play of the same name by British playwright Peter Morgan, who also adapted the screenplay. ${ }^{21}$ The film features Michael Sheen as Frost and Frank Langella as Nixon, the original stars of the West End and Broadway productions of the play. Howard agreed to direct only on the condition that they reprise their roles in the film. ${ }^{22}$ Frost/Nixon was a critical success after its premiere, earning $92 \%$ on Rotten Tomatoes and four out of four stars from renowned critic Roger Ebert. ${ }^{23}$ Ebert highlights both Langella and Sheen's effective depiction of their characters, acclaiming the renditions as embodiment rather than that of mere shallow impersonation. ${ }^{24} \mathrm{He}$ adds that Ron Howard's attention to historical detail complements the film, but he ultimately believes that the film's success boils down to the intensity of the acting, transforming it into a "spellbinding thriller". ${ }^{25}$ Following its immense critical praise, Frost/Nixon went on to be nominated for 5 Oscars: Best Picture, Best Actor (Langella), Best Director, Best Adapted Screenplay, and Best Editing. ${ }^{26}$

Frost/Nixon is largely true to history in its depiction of the interviews. Ron Howard's use of authentic locations, such as Nixon's house in San Clemente and Frost's original hotel suite, further assimilates the viewer into the time period with authenticity. ${ }^{27}$ But like all historical cinematic narratives, Frost/Nixon is not without its artistic license. The film modifies various aspects of the interviews, on and off the screen. The effect is a brilliant piece of cinema. The visual dedication to historical accuracy, however, such as Howard's shooting on historic locations, may dupe the viewer into thinking all the eventsor lines in the interviews - are true to reality. The inaccuracies, albeit few and subtle in comparison to most historical films, must be addressed for clarification.

First, Frost/Nixon omits a crucial aspect of the monetary negotiations between Frost and Nixon's team. It is true that Frost and Swifty Lazar settled on a payment of $\$ 600,000$ after lengthy debate, but the film neglects the detail that Nixon would be awarded an additional 20 percent of the profits. ${ }^{28}$ This fact suggests that Nixon, in addition to Frost, knew the interviews had to "sell" and be exciting in order to make money. Although it cannot be said for sure whether this component of the deal affected Nixon's performance in the interviews, it is worthwhile to consider since the ex-President liked to capitalize on his character. ${ }^{29}$ Sources do not 
reveal whether the omission of Nixon's 20 percent profiteering from the film was intentional or unconscious, but the detail is worthwhile to address as it raises questions about Nixon's motives.

While the aforementioned is a trivial detail, the film's arresting scene of Nixon drunkenly phoning Frost is pure fiction. In that portion of the film, Nixon alternates between being aggressive and pensive, desperate to "win" against Frost at any cost. David Frost himself called the fictionalization a "masterpiece" and it is advantageous because its premise is rooted in fact. ${ }^{30}$ Peter Morgan penned the scene after being inspired by the well-known midnight phones calls Nixon made to aides during Watergate. ${ }^{31}$ Moreover, it illustrates that Nixon had a drinking problem. Throughout his presidency, Nixon abused his martinis, scotch, and wine, and easily lapsed into drunkenness. ${ }^{32} \mathrm{He}$ had an aggressive temperament, paranoid personality, and often engaged in tantrums in presence of his aides; drunken episodes only enhanced these mood swings. ${ }^{33}$ With this on display during the phone exchange, the film offers a glimpse into Nixon's true intricate and tortured psyche. The scene intensifies the relationship between Frost and Nixon and powerfully engages the viewer. Though Nixon never drunkenly phoned Frost, the film demonstrates its brilliance by presenting fiction that is melded with fact.

\section{Although Frost/Nixon primarily} depicts the interviews accurately, often down to the exact dialogue, there are nevertheless various discrepancies with the historical record. The film's climactic scene of Frost eliciting an apology out of Nixon is the stuff of fiction. Nixon's defiant declaration, "When the president does it, that means it is not illegal," was extracted from a different recording session and placed in the Watergate interview. Nixon uttered this line in an interview dedicated to his approach to civil unrest, and in response to Frost's inquiring about the Huston Plan ("So in a sense you're saying ... the president can decide that it's in the best interest of the nation or something and do something illegal?"). ${ }^{34}$ The Huston Plan, which Nixon ratified in 1970, was an attempt to gain intelligence information by use of electronic surveillance and opening letters. Though he ended up revoking it, it was a "clearly illegal" technique that "amount[ed] to burglary" and came to light during the Watergate trials. ${ }^{35}$ The misplacement of "When the president does it..." is forgivable since Nixon's perspective on the Huston Plan is akin to his defensive attitude toward his role in Watergate, but the context is nonetheless distorted and misleading. Further, the film embellishes Nixon's tone, undoubtedly for theatrical effect. Film Nixon, eyes beady and lips trembling, gruffly shouts it with an air of disdain; the real Nixon softly states it as an almost cavalier matter-of-fact. Film Frost responds with a stunned, "I'm sorry...?"; the real Frost swiftly bounces back with, "By definition?". 36

Following the startling admonition, Frost begins to reel Nixon in and coaxes him to admit that he was part of a cover up. Jack Brennan immediately emerges from a viewing room and orders the cameras to cease rolling. Apprehensive, he suggests his boss should think things through before proceeding with any "emotional disclosures." 37 Though there was a break before Nixon issued his confession, and he and Brennan did confer, the film falsely depicts the reasoning for the break. Brennan actually came out with a sign that said, "Let him talk" as a signal to Frost not to interrupt Nixon. Frost mistakenly read it as "Let us talk" and volunteered to halt for a tape change. ${ }^{38}$ The film impresses that 
Nixon's team was vigilant in preventing him from making a confession, when this was not the case: Brennan evidently encouraged Nixon to proceed. The anticipated confession itself, however, is perhaps the film's most glaring falsehood. Nixon meekly discloses, "And I was involved in a 'cover up', as you call it."39 Although the real Nixon did confess to letting the American people (and many others) down, and having to "carry that burden with me for the rest of my life" he never admitted to being in a cover up. ${ }^{40}$ What he really said was, "You're wanting me to say that I've participated in a legal cover up-no!"41 One who watches Frost/Nixon with no knowledge of the real history may be impelled to believe that Nixon truly admitted to his active involvement in Watergate-a dangerous insinuation for the film to make. Nixon not only avoided admitting to being criminally involved in a cover up, but bluntly denied it.

There are other inaccuracies in Frost/Nixon, albeit comparably minor, but still worth addressing. Contrary to what the film suggests, Frost and Nixon had met before: Frost interviewed Nixon during his presidential campaign in $1968 .^{42}$ Their familiarity in the real interviews is more apparent, while the film suggests their unfamiliarity contributed to the crushing tension. There is also a scene in which Frost "crack investigator," James Reston, Jr., discovers crucial damning evidence against Nixon the day before the Watergate interview. Reston actually made the find eight months prior to the interviews. ${ }^{43}$ Finally, the movie depicts the Watergate interview to have been the twelfth and final taping session. In reality, that segment was filmed in the middle between sessions eight and nine. ${ }^{44}$ Amongst these inaccuracies, whether significant or minute, one must remember that Frost/Nixon is a film and not a documentary. Certain liberties must be taken to engage the viewer. The weightiest historical gripe is the one-line misrepresentation of Nixon's confession. All other fictionalizations are forgivable because they effectively heighten the film's electric atmosphere without betraying history too harshly. In this respect, Frost/Nixon is altogether a superb depiction of the real interviews.

As a film that dazzles with exhilarating drama, and one that holds more factual merit than most history-based films, Frost/Nixon's biggest draw is ultimately Nixon himself. In American memory, Nixon is synonymous with the greatest political scandal in American history. Thus, media depictions often deprive Nixon of any individuality and humanity. He becomes a character rather than a man, sometimes verging to the point of a nearly cartoonish villain (he is literally portrayed as such in Futurama). ${ }^{45}$ Frost/Nixon shatters this trend. What sets the film apart from all preceding Nixon portrayals is its effective venture to explore Nixon's rarely represented human side: complexities reign over lazy caricature.

Though Nixon's nuanced persona in the film can partly be attributed to Peter Morgan's skilled writing, it is Frank Langella's masterful interpretation that makes Frost/Nixon's Nixon so alluring yet revealing. In his book recalling the interviews, David Frost emphasizes how Langella "was Nixon”. ${ }^{46}$ Similarly, James Reston, Jr., attests that watching Langella was "truly like thirty years ago" as Langella's face distorts and sweats, his eyes darting side to side and words continually stumbling over one another (it should be noted that Reston's description was based off Langella's acting in the play, but Langella carries that same performance over to the film). ${ }^{47} \mathrm{He}$ is gruff and staunch, yet 
retains a softness that renders Nixon nearly sympathetic. The audience is offered a peek into Nixon's mentality, and there is consequently some context behind his motives. Langella stated that he had to actively resist succumbing to the classic Nixon clichés - the shaking jowls, V-signs, and inclination toward corruption - the typical fashion that American audiences want to see him depicted as. ${ }^{48}$ His effort shines in a performance that is clearly layered and meticulously well-acted.

Though the film's groundbreaking efforts to humanize Nixon is honorable, it teeters a fine line between sympathy and reproof. Langella's performance can be likened to a dichotomy: He is the sly and raw Nixon on camera in the interviews (despite some occasional and expected theatrics, recalling the confession scene) and during the drunk phone call, but — in a first for any portrayal of Richard Nixon-he is perhaps too sympathetic in the remainder of the film. As Nixon wanders around the interview set, he is almost Reagan-like. ${ }^{49}$ He sports a poised, humble demeanor and quiet comic affability. He artfully, almost endearingly, plays the piano for his admirers and emanates a cool air about him. The real Nixon was awkward and pretentious, and nothing of the sort. ${ }^{50}$ One of the most memorable lines in the film, when Nixon asks Frost, "Did you do any fornicating [last night]?" seconds before the cameras begin rolling, is played for humorous effect. One may consider it too bizarre to be true, and an effort to make Nixon appear outlandish. Yet truth is stranger than fiction. Nixon, ever the eccentric individual, did in fact ask Frost if he had "fornicated," but did so in an awkward attempt to converse with Frost on the set of the interviews (there are conflicting accounts as to which day Nixon said this, either during the tapings or after they had wrapped, but the fact remains that he nonetheless said it). ${ }^{51}$ The film utilizes this line to showcase Nixon's infamous "Tricky Dick" persona, but, had it used the line in its actual context, it would have revealed Nixon to be the perplexing and socially awkward man that he really was.

In actuality, Nixon was a mercurial and seemingly impenetrable individual. When he was president, his aides thought him to be several people at once: polite and generous, thoughtful and impetuous, but also a "hating, vindictive, cruel man." 52 As illustrated in the drunken phone call to Frost, Nixon had a ferocious temper and frequently engaged in threats and tantrums. ${ }^{53} \mathrm{He}$ was ruled by his own insecurities and jealousies, with a hatred for the press, "liberal establishment," "fucking academics," and "goddamn Ivy Leaguers." 54 He even fostered an intense envy for his National Security Advisor and later Secretary of State, Henry Kissinger, as Kissinger was everything Nixon was not: lionized and socially popular with a glamorous social life. ${ }^{55}$ Unbeknownst to Kissinger, he also became a scapegoat for Nixon's vicious anti-Semitism; Nixon would frequently refer to him as a "Fucking Jew" or "My Jew Boy." 56 Despite his vast array of personal negative qualities, Nixon tried to mask himself with the aspirations of being a great leader. He wanted to be defined as "the" foreign policy president, and actively strived to emulate the character of great leaders such as Charles de Gaulle. ${ }^{57}$ In his memoirs, he sought to defend himself by wielding "forgetfulness" as an excuse for any instance of wrongdoing. ${ }^{58}$ While doggedly ambitious, Nixon's endeavors to develop and preserve his legacy clearly proved to be fruitless. He epitomized how relentless immortal yearnings may manifest to be one's ultimate downfall. ${ }^{59}$ Of course, films that portray Nixon too often exploit this image, which facilitates his becoming of more of a 
myth than a man. Frost/Nixon tried to mitigate this image, gently evoking that Nixon was a self-made man with a classically tragic element of self-destruction. Langella may have portrayed him with a little too much empathy, but the slight character deviation provides a much-needed fresh perspective of Nixon as a person: a reminder that there was still a man behind the amoral politician.

In American memory, President Richard Nixon has become synonymous with the greatest political scandal in the nation's history. Watergate symbolized the destabilization of public trust in government, and marked a new era for investigative journalism. Nixon came from nothing and made a name for himself, though that name became commemorated into epithets of "crook" and "Tricky Dick". Frost/Nixon challenges this status quo view on Nixon, and humanizes him by exposing the man behind the marionette. Whether one despises him for his crimes or reveres him for his arguably tragic fall, Richard Nixon's mark in American memory cannot be contested. 
${ }^{1}$ Times, "Richard Nixon; Obituary", 1994, accessed March 7, 2017,

http://search.proquest.com.libproxy.temple.edu/docvie w/318110980?pq-origsite=summon.

${ }^{2}$ Ibid.

${ }^{3}$ Ibid.

${ }^{4}$ Ibid.

${ }^{5}$ Ibid.

${ }^{6}$ New York Times, "The 37th President; Richard Nixon, 81, Dies; A Master of Politics Undone by Watergate", 1994, accessed March 7, 2017, http://www.nytimes.com/books/98/06/14/specials/nixon -obit.html.

${ }^{7}$ Ibid.

${ }^{8}$ Times, "Richard Nixon; Obituary".

${ }^{9}$ Ibid.

${ }^{10}$ New York Times, "The $37^{\text {th }}$ President; Richard Nixon, 81, Dies".

11 Times, "Richard Nixon; Obituary".

12 Ibid.

${ }^{13}$ Godfrey Hodgson, "Obituary: Richard

Nixon", Independent, 1994, accessed March 7, 2017, http://www.independent.co.uk/news/people/obituaryrichard-nixon-1372361.html.

${ }^{14}$ Ibid.

15 Ibid.

${ }^{16}$ Ron Howard, Frost/Nixon, film (Hollywood:

Universal Pictures, 2008).

${ }^{17}$ Ibid.

18 Ibid.

${ }^{19}$ Ibid.

20 "Frost/Nixon (2008)", IMDB, last modified 2017, accessed April 18, 2017, http://www.imdb.com/title/tt0870111/?ref_=ttloc_loc_tt

21 "Frost/Nixon (2008) Trivia", IMDB, last modified 2017, accessed April 18, 2017, http://www.imdb.com/title/tt0870111/trivia?ref_=tt_trv trv.

${ }^{22}$ Ibid.

23 "Frost/Nixon (2008)", IMDB.

${ }^{24}$ Roger Ebert, "Frost/Nixon Movie Review \& Film Summary (2008) | Roger Ebert", Rogerebert.Com, last modified 2008, accessed April 5, 2017, http://www.rogerebert.com/reviews/frostnixon-2008.

25 Ibid.

26 "Frost/Nixon (2008)", IMDB.

27 "Frost/Nixon (2008) Trivia," IMDB.

${ }^{28}$ David Frost and Robert Zelnick, Frost/Nixon: Behind the Scenes of The Nixon Interviews, 1st ed. (New York:

Harper Perennial, 2007), 9.

${ }^{29}$ Elizabeth Drew, Richard M. Nixon (American

Presidents Series) (New York: Times Books - Henry

Holt and Company, 2007), 147.

${ }^{30}$ Frost and Zelnick, 4.

31 "Frost/Nixon (2008) Trivia," IMDB.
${ }^{32}$ Drew, 26.

${ }^{33}$ Ibid. 28.

${ }^{34}$ Frost and Zelnick, 84 and 89.

${ }^{35}$ Keith Olson, Watergate: The Presidential Scandal That Shook America (United States: University Press of Kansas, 2016), 16.

${ }^{36}$ Ron Howard, Frost/Nixon; Frost and Zelnick, 89.

${ }^{37}$ Ron Howard, Frost/Nixon.

${ }^{38}$ Frost and Zelnick, 118.

${ }^{39}$ Ron Howard, Frost/Nixon.

${ }^{40}$ Frost/Nixon: The Original Watergate Interview, 1977.

${ }^{41}$ Ibid.

${ }^{42}$ Frost and Zelnick, 6.

43 Ibid. 4.

${ }^{44}$ Ibid.

${ }^{45}$ Gary McMahon, "Nixon Vs. Nixon On Film", Film International 8, no. 5 (2010): 18, accessed March 7, 2017.

${ }^{46}$ Frost and Zelnick, 5.

${ }^{47}$ James Reston, Jr., The Conviction of Richard Nixon: The Untold Story of The Frost/Nixon Interviews (New York: Harmony Books, 2007), 181.

${ }^{48}$ Frank Langella, "Theater Talk: Frank Langella On Playing Richard Nixon in "Frost/Nixon."", PBS Theater Talk interview by Susan Haskins and Michael Reedle, TV (New York, 2007).

${ }^{49}$ Gary McMahon, "Nixon Vs. Nixon On Film", 20.

${ }^{50}$ Ibid.

${ }^{51}$ Frost and Zelnick, 77; Reston, 164.

52 Drew, 29.

53 Ibid. 28.

54 Ibid. 147.

55 Ibid. 65.

56 Ibid. 29

${ }^{57}$ Ibid. 61, 32, 35.

${ }^{58}$ Richard Nixon, RN: The Memoirs of Richard Nixon, PDF, 1st ed. (New York: Grosset \& Dunlap, 1978), accessed April 11, 2017, http://nsarchive.gwu.edu/NSAEBB/NSAEBB348/nixon .pdf, 4.

${ }^{59}$ Frank Langella, "Theater Talk". 


\section{Works Cited}

\section{Primary Sources}

Frost/Nixon: The Original Watergate

Interview, 1977.

Frost, David, and Robert

Zelnick. Frost/Nixon: Behind the Scenes of

The Nixon Interviews. 1st ed. New York:

Harper Perennial, 2007.

Langella, Frank. "Theater Talk: Frank

Langella on Playing Richard Nixon in

"Frost/Nixon.". PBS Theater Talk Interview

by Susan Haskins and Michael Reedle. TV.

New York, 2007.

Reston, Jr., James. The Conviction of Richard

Nixon: The Untold Story of The Frost/Nixon

Interviews. New York: Harmony Books, 2007.

Nixon, Richard. RN: The Memoirs of Richard

Nixon. PDF. 1st ed. New York: Grosset \&

Dunlap, 1978. Accessed April 11, 2017.

http://nsarchive.gwu.edu/NSAEBB/NSAEBB

348/nixon.pdf.

\section{Secondary Sources}

Drew, Elizabeth. Richard M. Nixon (American Presidents Series). New York: Times Books Henry Holt and Company, 2007.

Ebert, Roger. "Frost/Nixon Movie Review \&

Film Summary (2008)", Rogerebert.Com. Last modified 2008. Accessed April 5, 2017.

http://www.rogerebert.com/reviews/frostnixon -2008 .

"Frost/Nixon (2008)". IMDB. Last modified

2017. Accessed April 18, 2017.

http://www.imdb.com/title/tt0870111/?ref_=ttl

oc_loc_tt.

"Frost/Nixon (2008) Trivia". IMDB. Last

modified 2017. Accessed April 18, 2017. http://www.imdb.com/title/tt0870111/trivia?re $\mathrm{f} \_=\mathrm{tt} \_$trv_trv.

Hodgson, Godfrey. "Obituary: Richard Nixon.” Independent, 1994. Accessed March 7, 2017.

http://www.independent.co.uk/news/people/ob ituary-richard-nixon-1372361.html.

Howard, Ron. Frost/Nixon. Film. Hollywood:

Universal Pictures, 2008.

McMahon, Gary. "Nixon Vs. Nixon On

Film". Film International 8, no. 5 (2010): 7-

22. Accessed March 7, 2017.

http://vv4kg5gr5v.search.serialssolutions.com. libproxy.temple.edu/?ctx_ver=Z39.88-

2004\&ctx_enc=info $\% 3$ Aofi $\% 2$ Fenc $\% 3$ AUTF $-$

$\underline{8 \& \mathrm{rfr} \_\mathrm{id}=\mathrm{info} \% 3 \mathrm{Asid} \% 2 \mathrm{Fsummon} . \text { serialssol }}$ utions.com\&rft_val_fmt=info $\% 3$ Aofi $\% 2 F f m t$ \%3Akev\%3Amtx\%3Ajournal\&rft.genre=artic le\&rft.atitle=Nixon+vs.+Nixon+on+film\&rft.j title=Film+International\&rft.au=McMahon\%2 C+Gary\&rft.date $=2010-01-01 \&$ rft.issn $=1651-$ 6826\&rft. volume $=8 \&$ rft. issue $=5 \&$ rft. spage $=8$ \&rft.epage $=22 \&$ paramdict $=$ en-US

New York Times. "The 37th President; Richard Nixon, 81, Dies; A Master of Politics Undone by Watergate," 1994. Accessed March 7, 2017.

http://www.nytimes.com/books/98/06/14/spec ials/nixon-obit.html.

Olson, Keith. Watergate: The Presidential Scandal That Shook America. United States: University Press of Kansas, 2016.

Times. "Richard Nixon; Obituary," 1994.

Accessed March 7, 2017.

http://search.proquest.com.libproxy.temple.ed u/docview/318110980?pq-origsite=summon. 